\title{
Executive Director's annual report,
}

\section{FY 1987}

\author{
By JoAn S. Segal \\ Executive Director, ACRL
}

\section{How the Association fared last year.}

\begin{abstract}
A CRL's Strategic Plan, adopted by the Board at the New York Conference in 1986, contains four goals and seven "Strategic Management Directions." These are:

\section{Goals}

I. To contribute to the total professional development of academic and research librarians.

II. To enhance the capability of academic and research libraries to serve the needs of users.

III. To promote and speak for the interests of academic and research librarianship.

IV. To promote study, research and publication relevant to academic and research librarianship.

\section{Strategic Management Directions}

1. Positioning ACRL as the most significant American association of academic and research libraries, librarians, and librarianship.

2. Managing the financial resources of ACRL by relying on sound budgeting and accounting principles.

3. Maintaining a dedicated and competent staff by depending on sound personnel practices.

4 . Seeking new members through a variety of recruitment techniques, while extending efforts to retain present members.

5. Supporting all elected and appointed officers.

6. Working collaboratively with other ALA units.

7. Providing a Headquarters office.

During the 1987 fiscal year, this Plan drove ACRL activity. Although no annual operating plan was prepared, the Association began to implement a number of strategies to meet its objectives.

\section{Achievements, 1986-1987}

ACRL exhibited a marked "bias for action" during the past year. Using the Strategic Plan as an outline, here are some of the major achievements:

Goals

I. Professional development.

- Six courses were offered at San Francisco, with 116 participants. 717 participants took courses at 118 local presentations. The local presentation program has been so successful in less than two years of operation that six times as many people now take the courses locally than at Conference.

- The professional development needs assessment survey told us that professional reading and attendance at conferences were the two most popular professional development activities. But $51.8 \%$ of the respondents take short continuing education activities sponsored by professional associations, library schools, or private firms, and $48.2 \%$ take courses with or without credit at a college or university. Highest participation rate in short courses was among those who received their library degrees between 1960 and 1979, and among those holding the positions of department head or assistant/associate dean. While only $10.8 \%$ of the respondents had taken an ACRL CE course, $46.4 \%$ said they would be interested in one in the future. Most likely to participate in the future are those in 
non-supervisory positions, or those holding the rank of supervisor. Courses on technology updates were first choice, with management second. $68.0 \%$ said they wanted to take courses in their region; $50.5 \%$ at their own institution, and $41.9 \%$ at their local chapter meeting, as opposed to $31.5 \%$ at an ALA Conference. Although $62.5 \%$ expressed a preference to learn in a classroom setting, the respondents would consider the following off-site delivery formats: videotape $40.5 \%$; computerassisted instruction, $34.2 \%$; courses by mail, $27.5 \%$; and interactive video disk, $26.6 \%$. A total of $56.3 \%$ supported their continuing education by a combination of personal and employer funds. Primary motivation for taking a CE course was to update skills; and $31.5 \%$ were interested in a certificate program.

- one course was offered jointly with the Northern Illinois University in Chicago in February, with 51 participants. More courses are planned for FY 1988.

- Three Humanities Programming Workshops were carried out: in Orlando, Florida, in November; in Tucson, Arizona, in February; and in Omaha, Nebraska, in April. There were 108 participants in all. In its three years of funding from $\mathrm{NEH}$, the program has led to 23 successful NEH proposals, and several more to state humanities councils. Sandy Donnelly carries major responsibility for the education and NEH programs.

- Major programs at the San Francisco conference included:

President's Program: Academic Colleagues in Concert, with administrators, librarians, and faculty members discussing their relationships on campuses.

CLS discussion groups on faculty/librarian relations, budgeting, networking, standards, microcomputers, document delivery, and other topics.

Audio-Visual Committee's program on libraries, computers, and AV units and how they might be integrated.

CJCLS Megabytes without Megabucks, on the use of inexpensive machines with lots of bang for the buck.

LPSS joint program with SRRT on alternative sources for public policy.

SEES program on acquisitions by exchange.

Bob Balay, of the Choice staff, appeared on a panel discussing reference book reviewing.

STS on Artificial Intelligence.

BIS Learning to Teach program, followed by their tenth anniversary celebration. Also cosponsored by BIS was the session on subject authorities in the online environment.

The last Women's Studies Discussion Group program (they are now a section) on information about women of color.

$U L S$ panel discussion on the politics of cooperation.

RBMS annual preconference; also a program on the book arts in the Bay area.
Cathleen Bourdon is the staff member who works closely with Sections and Committees on their programming activities.

-During the year, the Chapter visits program supported eight visits by ACRL officers or staff to chapters, as follows:

October 3, Ohio Chapter, Segal; October 16, Minnesota Chapter, Rader; October 23, Oregon/Washington Chapter, Segal; November 14, Alabama Chapter, Hogan; April 2, New Mexico Chapter, Hogan; April 24, eight-state regional meeting, Bourdon; April 24, Iowa Chapter, Euster; July 31, Colorado Chapter, Segal.

Emma Miller (Alia Al-Taqi) is in charge of chapter activities.

-ACRL presented the following awards:

Academic or Research Librarian of the Year: Duane Webster.

Miriam B. Dudley Bibliographic Instruction Librarian of the Year: Evan Ira Farber.

Martinus Nijhoff International West European Specialist Study Grant: Michael Albin.

Samuel Lazerow Fellowship: Margaret Ann Johnson.

ISI Doctoral Dissertation Award: Ling Hwey Jeng.

Oberly Award: Jacqueline A. Ashby and Stella Gomez.

RBMS Exhibition Catalogue Awards: John Carter Brown Library; Houghton Library, Harvard University; University of Michigan Library; Honorable Mention: Houghton Library, Harvard University; Princeton University Library: Southern Methodist University Library; National Archives and Records Administration; University of Toledo Library; Kent State University; and the University of Virginia Library.

The staff member with responsibility for awards is Mary Ellen Davis.

II. Enhance libraries' capacity to serve users.

- The Ad Hoc Committee on Performance Measures identified twelve major areas of measures, which were refined by consultant Nancy Van House. An RFP seeking an author for an Output Measures Manual, was presented to the ACRL Board for their approval at the San Francisco Conference. Mary Ellen Davis worked closely with the Committee on this effort.

- 3,997 copies of ACRL standards were distributed free upon demand. Copies of the new College Library Standards were mailed to all accrediting bodies. Dawn Jacobson handled standards distribution.

- The ULS University Library Standards Committee continued to hold hearings and prepared a first draft of its work.

- Further work was done to test the possibility of ACRL's becoming a major collector of statistics about academic libraries. The Academic Library Statistics Committee carried out the survey of nonARL university libraries and tested a questionnaire developed with the collaboration of the U.S. De- 
partment of Education's Center for Education Statistics (CES). The questionnaire, which closely follows the IPEDS form, proved very successful. The Committee believes it would be possible for ACRL to collect data for a large universe of academic libraries and make it possible for libraries to have comparable data more frequently than every four years, as now planned by OMB. The cost of such a product is high. The ACRL Board authorized the Committee to seek funding for a field test of all academic libraries.

Mary Ellen Davis has carried out much of the work on the pilot project and preparation of a vendor information request and on the publication emerging from the activity.

- The Andrew Mellon Foundation has agreed to provide $\$ 20,000$ to fund a planning project aimed at determining what ACRL might do to help support libraries in Historically Black Colleges and Universities.

\section{Advocacy}

- ACRL has been successful in establishing several strong links with higher education associations. The Executive Director served on the Advisory Committee to the Regional Symposium on Campus Information Systems, sponsored by the Association of American Colleges and OCLC. The first of three was held in June in Alexandria, Virginia. Eight colleges were selected to participate after 33 submitted proposals.

-The National Association of College and University Business Officers (NACUBO) has agreed to an exchange of articles in CURL News and The Business Officer.

-AAUP and ACRL will work together on one or more workshops for librarians and faculty members.

- A response to the AASCU report, To Secure the Blessings of Liberty has been drafted by Artemis Kirk and forwarded to AASCU as a beginning to a cooperative relationship.

- Sharon Rogers has continued to serve on the AAHE Committee preparing a manual for recruiting top academic administrators, including library directors.

- Ronald Epp, Choice managing editor, and I authored a response to the ACLS survey of scholarly communication. This appeared in the February issue of $C \triangleleft R L$ News.

- Two mailings on important legislative issues were prepared by the ACRL Legislation Committee and the ALA Washington Office and were mailed to members by ACRL staff.

- Staff has cooperated with the ACRL Task Force on Fundraising and the LAMA Fund Raising and Financial Development Section in developing a proposal for an ALA Fundraising Clearinghouse.

IV. Publications and Research.

It seems trite to record the regular publication of serials, but it is a considerable achievement to note that in FY 1987, ACRL has published, in a timely fashion:
11 issues of $C \& R L$ News;

11 issues of Choice;

6 issues of $C \downarrow R L$;

2 issues of $R B M L$;

3 issues of Chapter Topics; and

22 issues of Section Newsletters.

Work on automating the Choice operation has resulted in selection of the H.W. Wilson Co. as the vendor. Conversion will take place in FY 1988.

Books for College Libraries, 3d edition, is nearing completion. It will be published early in 1988 .

Mary Ellen Davis is in charge of non-serial publications. Non-serial publications this fiscal year include:

\section{ACRL staff profile}

Sandra Donnelly, ACRL's continuing education officer, has been on the ACRL staff for two and a half years. Donnelly's main responsibilities include developing and coordinating the $\mathrm{CE}$ courses, coordinating workshops for the NEH grant that ACRL shares with the Public Library Association, and managing the exhibits for ACRL's national conferences.

In addition to those three main areas of responsibility, Donnelly is under a contractual agreement with PLA to manage their exhibits for their 1988 national conference.

Before coming to ACRL, Donnelly was with the College of DuPage, Illinois, where she was manager of the Health and Human Services program. Her position focused on outreach to community institutions, organizations and agencies with the goal of cooperative continuing professional education for health and human service professionals.

During the time Donnelly has been with ACRL there has been a shift of focus in the CE program from only offering courses at ALA and ACRL conferences to offering courses cooperatively on the local level. ACRL began local presentation programs in November 1985. They have grown from 12 programs in FY 1986 to over 20 programs in FY 1987.

Donnelly is also cooperating with Northern Illinois University and the University of Wisconsin on regional programs. She has initiated cooperative programming with ALA's Library Administration and Management Association for FY 1988 and 1989.

This year ACRL's CE program will be reshaped to align the CE offerings more closely with member needs and ACRL resources. 
$\# 8$;

- Periodicals in College Libraries: CLIP Note

- ACRL University Library Statistics 1985-86

and 1986 "100 Libraries" Statistical Survey;

- Managing Student Workers in College Libraries: CLIP Note \#7;

- Printing and Publishing Evidence: Thesauri for Use in Rare Book and Special Collections Cataloguing;

- Library Instruction Clearinghouses.1986: A Directory;

- Library Statistics of Colleges and Universities, 1985: National Summaries, State Summaries, Institutional Tables.

George Eberhart is editor, Gus Friedlander assistant editor of $C \triangleleft R L$ News; $C \& R L$ and $R B M L$ have volunteer editors: Charles Martell and Ann Gwyn. Alia Al-Taqi produces Chapter Topics.

Gus Friedlander is responsible for Section Newsletters.

Patricia Sabosik is editor and publisher of Choice; and Virginia Clark is editor of Books for College Libraries.

B. Strategic Management Directions. This part of the plan contains 7 statements regarding the management of ACRL. While they are very general, they do constitute a way of categorizing much of the administrative work of the Division.

1. Development.

- Planning activities have included a staff retreat in September, Midwinter Meeting discussions by committees, sections, and Chapters Council, and the development by staff of a draft of the first annual planning document. Several new projects began to be developed, including a research workshop, planning workshop, and faculty/librarian workshops.

\section{Finances.}

- ALA's new chart of accounts has been used to prepare the 1988 budget. The first financial orientation was held for the Board and Budget and Finance Committee. The Budget and Finance Committee, jointly with the Planning Committee are working on a policy for allocating surplus funds.

- ACRL's financial condition remains very strong. Generous fund balances have allowed the division to absorb the impact of accrual accounting without imperiling the ACRL 6-month "reserve" fund. The anticipated fund balance at the end of FY 1987 is $\$ 585,865$.

- Financial reports have been presented regularly to the Budget and Finance Committee and the Board.

3. Personnel.

- Staffing at Headquarters has stabilized, with only one turnover this year. Vivian Hunter left ACRL in December. Sheryl Stephens became administrative assistant in February. Senior staff meetings were initiated in the fall and have provided a forum for sharing information, giving and receiving assistance with operational problems, and participating in management decisions.
- An exciting new activity is the quality circle implementation. We first became aware of q.c.'s in some of Charles Martell's writing. We looked into the movement and made a commitment to have a staff member trained, which took place in the spring. Our "zero meeting" was held in May and implementation will begin-on a nonmandatory basis - in the fall.

- The ACRL staff is very strong. They have experience in running the Association and each has expertise in specific areas. As a division, ACRL is very lucky to have enough staff to carry out a large number of projects, and staff members of high quality, who are all aware of the ACRL overall program and able to assist members when they call, write, or meet them in person. Communication with Choice staff has included monthly meetings, alternately in Connecticut and in Chicago (or at Midwinter Meeting and Annual Conference).

4. Membership.

- Rate of growth has slowed appreciably and ACRL must look at new strategies for recruiting and retaining personal and organizational members. ALA-wide plans for increasing organizational membership are attractive and ACRL might be able to participate in them.

\section{Leadership.}

- Orientation programs have been initiated for the Budget and Finance Committee and for all new committee and section chairs. The first orientation took place in San Francisco. ACRL leaders receive a regular update of Association activities.

\section{ALA collaboration.}

-ACRL staff members have served ALA on several committees, including the Staff Association (C. Bourdon, President, S. Donnelly, floor rep., M.E. Davis, Personnel Subcommittee); Job Evaluation Committee (C. Bourdon); Data Processing Steering Committee (J. Segal); staff team for Planning Committee (J. Segal); Team on Business Plan (J. Segal); and Pre-Press Committee (G. Eberhart).

-We published a comparison of the ALA and ACRL plans to indicate similarity of goals.

\section{Headquarters.}

- Staff has been rather crowded since we increased the number (not FTE) of staff last year. Recent acquisition of new computer equipment has upgraded our ability to produce documents and do analysis, but has further cramped the staff. The new equipment was selected to offer compatibility with ALA systems, including the McDonnell Douglas membership and finance systems (DMG), the ALA Publishing Pre-Press System, and potentially the Wang System.

- We have used Headquarters as a meeting place for the Executive Committee, Academic Library Statistics Committee, Cincinnati Planning Committee, Fundraising Clearinghouse Planning Group, and informal meetings with individual officers and members.

- ALANET has been used for communication. 


\section{Conclusion}

ACRL has had another good year. Programmatically, several new ideas are under development.
The strength of member commitment, which drives the organization, is excellent and we can look forward to another good year.

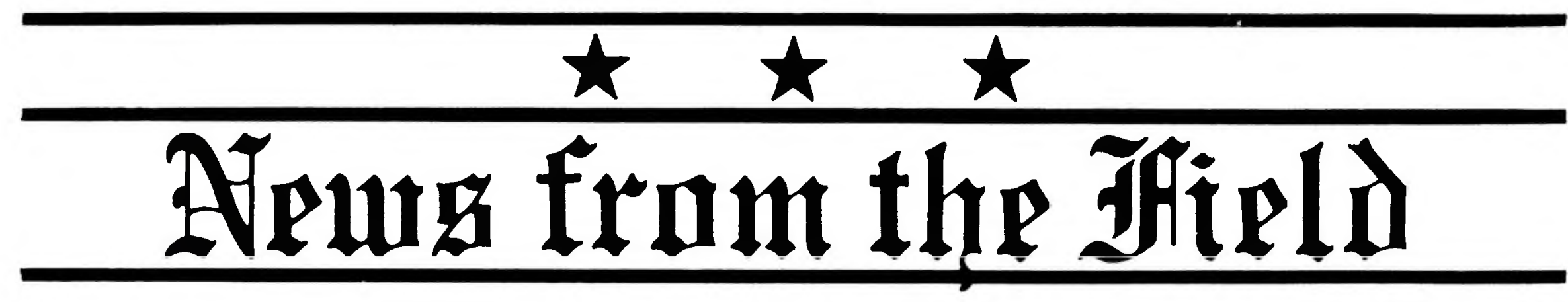

\section{Acquisitions}

- Bennington College, Vermont, has received more than 2,000 works on theater, including plays, historical studies, critical works, and other texts, from the estate of the late Edward T. Kirby. Kirby, who died in 1985, was a noted playwright and the author of Ur-drama: The Origins of Theater. The collection includes works on Greek and Roman theater; medieval drama; Tudor drama; Chinese, Siamese and Indian drama; and rare volumes on the Japanese Noh theater. There are also a number of important works by important Russian directors, playwrights and drama theorists as well as authoritative histories and reference works. Among notable foreign works is Les voies de la creation theatrale, a survey of plays, theatrical essays and photographs edited by Denis Bablet.

- The University of Illinois at Chicago has received the archives of the annual International Design Conference at Aspen (IDCA). The brainchild of Walter Paepcke, head of Container Corporation of America, IDCA was inagurated to Provide a forum for designers to engage in discussions of the quality of design and the relationship design has with business and to exchange ideas with their peers from around the world. The IDCA archive preserves the papers and presentations of a large number of internationally known designers and businessmen including Ivan Chermayeff, Charles Eames, R. Buckminster Fuller, Gyorgy Kepes, and Frank Stanton. Over the years, Chicago designers, including Robert Hunter Middleton, Bruce Beck, Jay Doblin, Morton Goldsholl, Albert Kner, John Massey, Herbert Pinzke and DeForest Sackett, have had major involvement. Among the materials in the archive are the official records of each conference, from the first in 1951 on "Design as a Function of Management" through the most recent in 1987 on "Success and Failure." In the collection are copies of papers presented, transcribed conference records, tape recordings of meetings, correspondence, and a wide range of graphic materials produced in conjunction with the conference.

\section{Grants}

- The Association of Research Libraries, Washington, D.C., has received a $\$ 45,000$ grant from the Council on Library Resources to conduct a third Institute on Research Libraries for Library and Information Science Faculty. The institute will be held in the summer of 1988, with 12 faculty participating. Previous institutes were held in 1984 and 1986, at which librarians and library and university administrators joined library educators in studying the forces that influence the current and future conditions of research libraries. The 1988 institute will concentrate on the library school curriculum as it relates to research libraries.

- Dalhousie University, Halifax, Nova Scotia, and Acadia University, Wolfville, have each received a $\$ 30,000$ grant from the Social Sciences and Humanities Research Council of Canada to support their specialized research collections in strategic studies. The funds have been provided to purchase microform collections of documents and reports in the fields of diplomatic history, international relations, military affairs and arms control. Dalhousie's major acquisitions will be of postWorld War II records of U.S. government agencies involved in military and diplomatic planning, such as the Joint Chiefs of Staff and the departments of Defense and State. Acadia's acquisitions will be of a similar nature but will concentrate on the preWorld War II period.

- Hofstra University, Hempstead, New York, has received $\$ 3,000$ from the New York State Discretionary Grant Program for the Conservation/ Preservation of Library Research Materials. The grant will be used for the deacidification, restoration, encapsulation, microfilming and cataloging of the holdings of the Macready/Meyer Theatrical Collection, a combination of books, handbills, playbills, manuscripts, and correspondence relating to the career of British Shakespearean actor William Charles Macready (1793-1873). Among the items are those which concern the infamous Astor Place Riots of 1849 , sparked by the rivalry be- 